DOI: https://doi.org/10.34069/AI/2021.45.09.5

How to Cite:

Marysyuk, K.B., Komnatnyi, S.O., Grygor`yeva, V.V., Prystai, T.M., \& Mital, O.H. (2021). Public-private partnership as a new form of social responsibility and a mechanism of decentralization of public administration. Amazonia Investiga, 10(45), 52-62. https://doi.org/10.34069/AI/2021.45.09.5

\title{
Public-private partnership as a new form of social responsibility and a mechanism of decentralization of public administration
}

\section{Державно-партнерські відносини як нова форма соціальної відповідальності та механізм децентралізації державного управління}

Received: August 17, 2021

Accepted: September 25, 2021
Written by:

Kostyantyn B. Marysyuk ${ }^{14}$ https://orcid.org/0000-0002-7483-3836

Serhii O. Komnatnyi ${ }^{15}$ https://orcid.org/0000-0002-2124-2047

Viktoriya V. Grygor'yeva ${ }^{16}$ https://orcid.org/0000-0002-4997-803X

Tatiana M. Prystai ${ }^{17}$ https://orcid.org/0000-0001-6180-2785

Olena H. Mital ${ }^{18}$ https://orcid.org/0000-0002-4101-3081

\begin{abstract}
The need to attract resources to socially significant infrastructure facilities, decentralize authority, market orientation of public services, efficiency and competition requires the search for a combination of opportunities for cooperation between the public and private sectors. A public-private partnership has become one of the modern approaches to the implementation of socially important projects. The study identified the degree of impact of the partnership between the state and business, as a mechanism of decentralization of public administration, on the factors of social responsibility. The methodological approach involved the analysis of the existing research on social responsibility of public-private partnership by identifying and comparing key factors of social responsibility; determination of variables that describe them, and conducting econometric analysis of established variables. It is proved that in addition to overcoming the budget deficit, contributing to economic performance, public-
\end{abstract}

\begin{abstract}
Анотація
Потреби в залученні ресурсів у соціально важливі інфраструктурні об’єкти, децентралізації функцій управління, ринковій орієнтації публічних служб, результативності та конкуренції вимагає пошуку поєднання можливостей співпраці державного та приватного сектору. Одним із сучасних підходів до реалізації соціально важливих проектів стало державно-приватне партнерство. У дослідженні було визначено ступінь впливу партнерства держави та бізнесу, як механізму децентралізації державного управління, на фактори соціальної відповідальності. В якості методологічного підходу використано аналіз змісту існуючих досліджень соціальної відповідальності державно-приватного партнерства шляхом виявлення та порівняння ключових чинників соціальної відповідальності; визначення змінних, які їх характеризують, та проведення економетричного аналізу встановлених змінних величин. Доведено, що крім подолання дефіциту бюджету, створення економічних
\end{abstract}

\footnotetext{
${ }^{14}$ Doctor of Law, Professor at the Department of Criminal Law and Procedure, Institute of Jurisprudence, Psychology and Innovative Education, Lviv Polytechnic National University, Lviv, Ukraine.

${ }^{15} \mathrm{PhD}$ in Pedagogy, Senior Lecturer of Department of Civil Law Disciplines, National Academy of Internal Affairs, Kyiv, Ukraine. ${ }^{16} \mathrm{PhD}$ in Law, Associate Professor at the Donetsk State University of Management, Department of Special Law Disciplines, Faculty of Law and Public Administration, Donetsk State University of Management, Mariupol, Ukraine.

${ }^{17} \mathrm{PhD}$ in Law, Associate Professor at the Department of State Legal and Branch Legal Disciplines, Kyiv University of Law of NAS of Ukraine, Kyiv, Ukraine.

${ }^{18} \mathrm{PhD}$ in Economy, Associate Professor at the Department of Hospitality Industry and Sustainable Development, V.I. Vernadsky Taurida National University, Kyiv, Ukraine.
} 


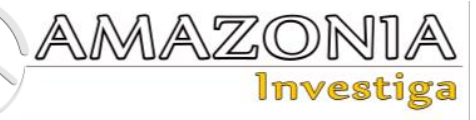

private partnership involves social responsibility. The activity of public-private partnerships (private investment in infrastructure projects) is found to have impact on innovation, the environment, health care, the rule of law, and unemployment rates. There is a need to conduct further research with an expanded number of countries and factors that describe social responsibility of public-private partnership.

Keywords: decentralization of authority, publicprivate partnership, social responsibility, state.

\section{Introduction}

The aim of the system of public administration is to influence public relations within its functional capabilities. Society development entails new needs, requirements, values aimed at improving the standard of living and its quality, improving the indicators associated with human life. Reforms in the public administration system are based on the processes of defining goals, organization, changes in the structure of society, combining the possibilities of public and private property. Such mechanisms enhance joint activities, increase efficiency, and provide the necessary results for society.

Public administration relies on law enforcement that allows implementing public issues, achieve social goals and joint decision-making within the authority of public institutions and disposal of public property. In recent decades, public administration has found innovative approaches to strengthening its capabilities. One of these areas is the decentralization of public administration. State resources are not enough to solve an increasing number of social problems. As a result, hybrid forms of governance are emerging that allow delegating some of the state's functions to those who can perform them more effectively, namely - the private owner.

The aim of this study is to determine the degree of influence of the partnership between government and business, as a mechanism of decentralization of public administration, on the factors of social responsibility. The study is to identify the features of public-private partnership as a mechanism for decentralization of public administration; analyse the definition of "social responsibility"; identify factors of social responsibility of PPP projects using existing approaches and research; determine the degree of dependence between private investment in PPP результатів діяльності, державно-приватне партнерство може нести соціальну відповідальність. Виявлено, що результати діяльності державно-приватного партнерства (приватні інвестиції в інфраструктурні проєкти) мають певний вплив на інновації, екологію, охорону здоров'я, показники верховенства закону, зниження безробіття. В подальшому $\epsilon$ необхідність проведення досліджень 3 розширеною кількістю країн та чинників, які характеризують соціальну відповідальність державно-приватного партнерства.

Ключові слова: децентралізація управління, державно-приватне партнерство, соціальна відповідальність, держава.

projects and the factors of social responsibility that have been established before.

\section{Literary review}

The concepts of the New Public Management became the ideas of this approach, which is based on minimizing the role of the state, decentralization of management functions, market orientation of public services, contracting, efficiency, competition. The new public management promoted public-private partnerships (PPPs) as a tool that combines the best benefits of public and private sectors in providing infrastructure, thereby reducing the financial burden on the state and achieving efficiency in project implementation. Under the New Public Management paradigm, the rule of law, capacity and trust create an institutional environment for the development of PPP projects (Casady, Eriksson, Levitt \& Scott, 2019).

Public-private partnership is seen as "a long-term contract between a private party and public authorities for the provision of public property or services, in which the private party bears significant risk and responsibility for management, and the reward is performancebased" (World Bank, 2019). PPPs are essentially a collaboration between public and private actors for mutual benefit (Sheppard \& Beck, 2016).

The implementation of public services in the course of public-private partnership has become widespread in the world, as it has shifted the emphasis of state dominance in the creation and distribution of public services. The goal of the PPP should be to increase the efficiency of the use of public funds through competitive management, sharing of risk and responsibility. 
In a situation of public finance shortage, infrastructure depreciation, increasing infrastructure deficits, and provided requirements for achieving the UN Sustainable Development Goals for infrastructure, countries currently face problems of infrastructure development (Mota \& Moreira, 2015). Today, the PPP model is used to meet the growing needs for infrastructure in many countries (Malik \& Kaur, 2020).

In addition to reducing the fiscal burden of countries, PPPs offer other benefits: attracting private funds, save money and time, helping to achieve better value for money and ensuring proper risk allocation (Rocca, 2017). PPP agreements provide for cooperation as well as distribution of responsibilities, and the main goal is to accumulate resources to build infrastructure. PPPs can be used to finance infrastructure in the "energy sector, transport, information and communication technologies, water supply and sanitation, as well as the social sector" (Malik \& Kaur, 2020). Due to these benefits, they are actively used to finance sustainable infrastructure (Casady et al., 2019).

Innovative approaches in the adoption of new technologies of public administration involve decentralization of public administration, that is reducing the boundaries of formation and realization of public authority through partner entities (business environment, nongovernmental institutions), as well as the realization of common interests, which provides for overcoming the negative consequences with excessive management costs, bureaucracy, centralization, etc. The logical evolutionary path of public-private partnership should be the introduction of mechanisms for the decentralization of power based on the joint implementation of state functions. This will strengthen the possibilities of state regulation, strengthen the development policy of various sectors of the economy, providing tools for public control. The proposed approaches will increase macroeconomic stability, standards of living, and social responsibility.

Although the economic factors produced by PPP projects are determined as key and measurable, the social component can be determined as significant contribution of public-private partnership. Implementation of PPP projects produces social effects that can affect unemployment, health care and other important factors. Given the importance of PPP for society, a necessary aspect of the study is the concept of "social responsibility". Social responsibility is seen as a commitment of business to contribute to sustainable economic development by working with employees, the local community and society as a whole to improve their lives in ways that benefit business and development (Popa, 2015). Social responsibility not only promotes sustainable development and local development, but also improves cooperation and relationships between society and organizations.

PPP researchers focus on the economic results of the partnership, and the study of social responsibility is not widespread enough in scientific literature. Today, social responsibility interpreted as "a theoretical approach to social and corporate governance, aimed at implementing the widely supported concept of 'economic growth for all' and the gradual overcoming of social inequality in modern societies" (Mulej, O’Sullivan \& Štrukelj, 2021, p. 97). Social responsibility is a concept that should be followed at the state level (social responsibility of the state). Social responsibility at the state level, also called social responsibility of the state, is the ability of legislation of a particular country "to ensure a high level of social welfare, economic and environmental sustainability, without further deepening of income inequality and violation of human (economic and social) rights" (Mulej, O'Sullivan \& Štrukelj, 2021, p. 35). Of the three foundations of sustainability - economic, environmental and social - it concerns only social sustainability. Responsibility is realized through ethical behaviour that promotes, among other things, sustainable development, improved health care and social well-being (Hinson, Avomyo, Kuada \& Asante, 2017).

The study of social responsibility factors in PPP projects ( $\mathrm{Yu}$ et al., 2018) identified 38 social responsibility factors, which were further analysed and classified according to various aspects of responsibility. The most widely reported factors of social responsibility in PPPs are: "creating a system of environmental management", "innovation" and "ensuring accountability, legality and transparency". In addition, factors related to healthcare, labour protection and safety, human rights, and providing jobs were identified. A similar list of social responsibility factors developed in (Yu et al., 2018) was taken as a basis for another study (Osei-Kyei et al., 2019).

In addition, the study (Chen et al., 2019) developed a model that can be used to assess the levels of sustainability of PPP projects. Four categories of social responsibility factors 


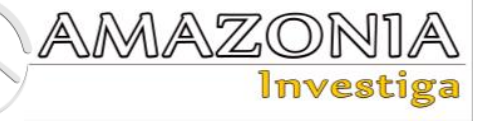

included in this model and they are: economic, environmental, social and people-oriented factors. Social factors received the highest coefficient in the PPP resilience index equation. This study identified factors related to PPP social responsibility: innovation, environmental management, ensuring accountability, legality and transparency, healthcare, and human rights.

PPP projects have a significant impact on the environment, citizens and society during their long life cycle; thus, social responsibility became critical in their development. As project companies seek to make a sufficient profit, they have to make significant efforts to propose social measures and promote sustainable development measures. In recent years, PPPs have used a variety of social responsibility factors, and these factors often focus on areas such as healthcare, education, sanitation, and philanthropy (Yu et al., 2018). Most of the social responsibility initiatives often adopted under the PPP focus on such areas as environmental protection, sanitation, education and transparency (Patil, Tharun \& Laishram, 2016).

\section{Methods}

The methodological approach of the study will be based on several stages: identification of key factors of social responsibility in PPP projects using existing approaches in modern research of the said factors; identification of indicators that can describe the established factors of social responsibility and econometric analysis to identify a significant set of factors.

Using the studies of social responsibility in public-private partnership (Chen et al., 2019; Osei-Kyei et al., 2019; Yu et al., 2018), the following factors of social responsibility were selected, which are important implications of PPP projects: innovation, environmental protection (ecology), healthcare, accountability and legality (rule of law) and unemployment reduction (providing jobs).

The number of PPP projects and PPP investments as a percentage of GDP are considered as important aspects of PPP activities (Yurdakul, Kamaşak \& Öztürk, 2021). The study focused on the amount of investment in PPP projects. In order to determine whether there is a dependence between social responsibility factors and the results of PPP development, we used the following data as variables: the total amount of investment in PPP projects (1990-2019), the Global Health Security Index, Environmental Performance Index, Global Innovation Index, Rule of Law Index and Unemployment Rate. The available complete data on these factors allowed studying the indicators of 69 countries. Data are taken from open sources from the World Bank, the Private Participation in Infrastructure Database, the Global Health Security Index, the Environmental Performance Index, the Global Innovation Index, and the Rule of Law Index (Table 1).

Table 1.

Variables Summary.

\begin{tabular}{|c|c|c|}
\hline Variable & Full description & Measuring \\
\hline PPPI & $\begin{array}{l}\text { The total amount of } \\
\text { private investment in } \\
\text { PPP projects (1990- } \\
\text { 2019) }\end{array}$ & USD million (World Bank, 2019). \\
\hline GHS & $\begin{array}{l}\text { Global Health Security } \\
2019\end{array}$ & $\begin{array}{l}\text { The Global Health Security Index measures countries' security and health } \\
\text { capabilities for six categories and } 34 \text { indicators. All data are rated on a scale } \\
\text { from } 0 \text { to } 100 \text {, where } 100 \text { is the best health care condition (Economist } \\
\text { Intelligence Unit, 2020). }\end{array}$ \\
\hline EPI & Index, 2020 EPI rank & $\begin{array}{l}\text { The Environmental Performance Index is an assessment of the state of the } \\
\text { environment and the viability of ecosystems around the world. Using } 32 \\
\text { performance indicators for } 11 \text { problem categories, the index assesses } 180 \\
\text { countries. Indicators are rated on a scale of } 0-100 \text {, from worst to best } \\
\text { (Wendling et al., 2020) }\end{array}$ \\
\hline GII & $\begin{array}{l}\text { Global Innovation } \\
\text { Index } 2020 \text { rankings }\end{array}$ & $\begin{array}{l}\text { The Global Innovation Index classifies innovation performance in more than } \\
130 \text { countries. Indicators are rated on a scale of } 0-100 \text {, from worst to best } \\
\text { (Dutta, Lanvin, \& Wunsch-Vincent, 2020). }\end{array}$ \\
\hline RLI & $\begin{array}{l}\text { Rule of Law Index } \\
2020\end{array}$ & $\begin{array}{l}\text { The Rule of Law Index provides an assessment of the rule of law in } 128 \\
\text { countries, providing ratings based on } 8 \text { factors. Indicators range from } 0 \text { to } 1 \text {, } \\
\text { with } 1 \text { indicating the highest level of observance of the rule of law (World } \\
\text { Justice Project, 2020). }\end{array}$ \\
\hline UNT & $\begin{array}{l}\text { Unemployment rate } \\
2020\end{array}$ & $\begin{array}{l}\text { Unemployment, total (\% of total labour force) (ILO (International Labour } \\
\text { Organization) simulated estimate (World Bank, 2020). }\end{array}$ \\
\hline
\end{tabular}

Source: author's development 
To determine the functional dependence of $\mathrm{y}=$ $f(\mathrm{x} 1, \mathrm{x} 2, \ldots \mathrm{xn})+\varepsilon$ of the resultant attribute $(\mathrm{y})$, namely the development of PPPI on factor attributes $(\mathrm{x} 1, \mathrm{x} 2, \ldots \mathrm{xn})$, which are characterized by indicators (GHS, EPI, GII, RLI, UNT) (Table 1 ), it is necessary to conduct a regression analysis, which has a theoretical form:

$$
\mathrm{Y}=\beta 0+\beta_{1} \mathrm{X}_{1}+\beta_{2} \mathrm{X}_{2}+\ldots+\beta_{\mathrm{n}} \mathrm{X}_{\mathrm{n}}+\varepsilon
$$

In equation (1) $\beta 0, \beta 1, \ldots \beta \mathrm{n}$ are vectors of dimension of unknown parameters, $\varepsilon$ is a member of a random error in equation. Functional dependence calculations will be performed using the Gretl software package.

\section{Results}

Based on the theoretical model, we build equation (2), which is an econometric model that determines the degree of dependence of the development of PPP (the amount of private investment) on the factors that describe social responsibility:

$$
\begin{gathered}
\ln \text { PPPI }=\beta_{0}+\beta_{1} \ln \mathrm{GHS}+\beta_{2} \ln \mathrm{EPI}+\beta_{3} \\
\ln \mathrm{GII}+\beta_{4} \ln \mathrm{RLI}+\beta_{5} \ln \mathrm{UNT}+\varepsilon
\end{gathered}
$$

where ln PPPI, ln GHS, ln EPI, ln GII, ln RLI, ln UNT - logarithms of values of the studied indicators.

Using the Gretl software package, the proposed model was evaluated using the least squares method (LSM). The results of the model values are given in Tables 2 and 3 .

Table 2.

Model: OLS, Using Observations 1-69; Dependent Variable: l_PPPI

\begin{tabular}{llllll}
\hline & Coefficient & Std. Error & t-ratio & p-value & $* * *$ \\
\hline const & -13.7468 & 4.71647 & -2.915 & 0.0049 & $* *$ \\
1_GHS & 2.66163 & 1.18327 & 2.249 & 0.0280 & \\
1_EPI & -1.70846 & 1.20144 & -1.422 & 0.1600 & $* *$ \\
1_GII & -4.26068 & 1.77431 & -2.401 & 0.0193 & $* * *$ \\
1_RLI & 4.43431 & 1.27343 & 3.482 & 0.0009 & $*$ \\
1_UNT & 0.577544 & 0.319684 & 1.807 & 0.0756 & \\
\hline
\end{tabular}

Table 3.

The results of Values for the Model

\begin{tabular}{llll}
\hline Mean dependent var & 8.433947 & S.D. dependent var & 2.052781 \\
\hline Sum squared resid & 167.1605 & S.E. of regression & 1.628908 \\
R-squared & 0.416636 & Adjusted R-squared & 0.370337 \\
F(6, 62) & 8.998869 & P-value(F) & $1.71 \mathrm{e}-06$ \\
Log-likelihood & -128.4340 & Akaike criterion & 268.8680 \\
Schwarz criterion & 282.2727 & Hannan-Quinn & 274.1861 \\
\hline
\end{tabular}

The results of testing the hypothesis of insignificance of the coefficients are as follows: The Global Health Security Index, the Global Innovation Index, the Rule of Law Index and the Unemployment Rate were significant. Moreover, * means that the indicator is significant at the level of $\mathrm{p}<0.1, * *$ - at the level of $\mathrm{p}<0.05$, and $* * *$ _ at the level of $\mathrm{p}<0.01$. The Environmental Performance Index in this model is not significant. The Global Innovation Index is negative, indicating an inverse dependence: as investment in PPPs increases, innovation performance deteriorates.

Test results of tests for the normal distribution of the model: Doornik-Hansen test $=3.2784$, $\mathrm{p}$ - value 0.194135; Shapiro-Wilk test $\mathrm{W}=$ 0.973755 , p-value 0.154638; Lilliefors test $=$ $0.096997, \mathrm{p}$-value $=0.11 ;$ Jarque-Bera test $=$ 2.58503 , p-value 0.274579 . For these criteria at the level of significance $\alpha=0.05$, the null hypothesis about the normality of the distribution of regression residuals is not rejected.

Let us check the normality of the distribution of regression residuals based on the Chi-square criterion. The frequency distribution for the model is shown in Figure 1 and Table 4. Null hypothesis - normal distribution: Chi-square $(2)=3.278, p$-value $=0.1941$ 


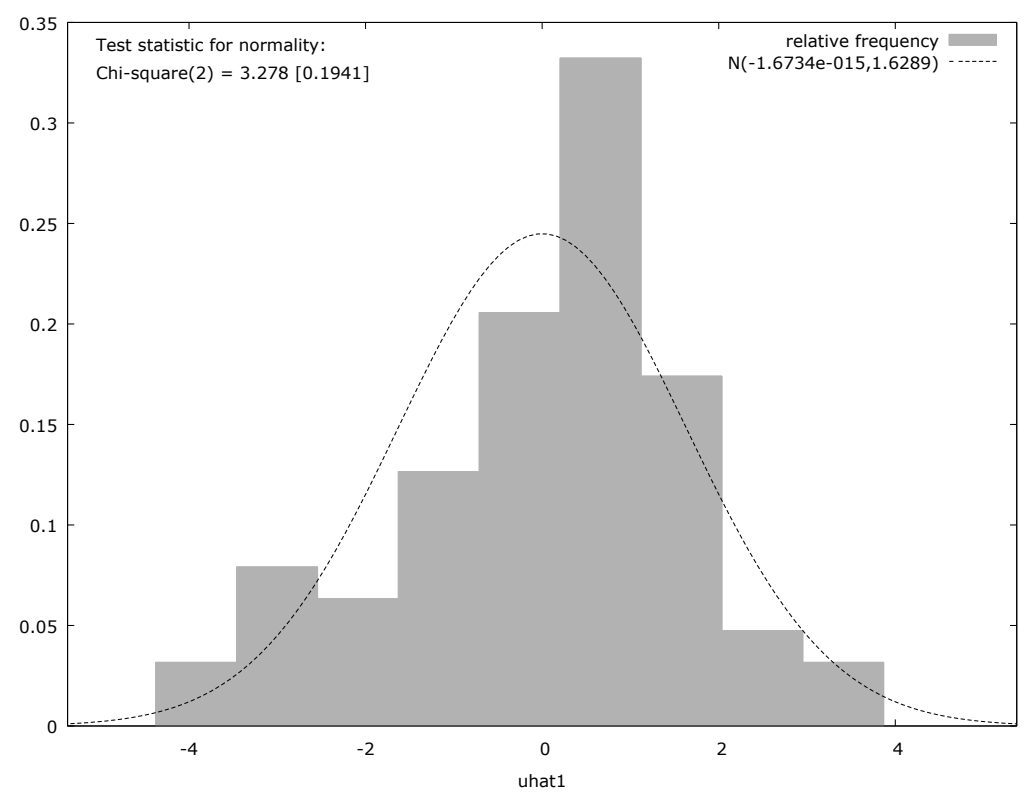

Figure 1. Frequency Distribution for the Model, Observations 1-69

Table 4.

Frequency Distribution for the Model, Observations 1-69

\begin{tabular}{lllll}
\hline Interval & Midpt & Frequency & Rel. & Cum. \\
\hline$<-3.4604$ & -3.9184 & 2 & $2.90 \%$ & $2.90 \% *$ \\
$-3.4604--2.5444$ & -3.0024 & 5 & $7.25 \%$ & $10.14 \% * *$ \\
$-2.5444--1.6284$ & -2.0864 & 4 & $5.80 \%$ & $15.94 \% * *$ \\
$-1.6284--0.71240$ & -1.1704 & 8 & $11.59 \%$ & $27.54 \% * * * *$ \\
$-0.71240-0.20359$ & -0.25440 & 13 & $18.84 \%$ & $46.38 \% * * * * * *$ \\
$0.20359-1.1196$ & 0.66159 & 21 & $30.43 \%$ & $76.81 \% * * * * * * * * *$ \\
$1.1196-2.0356$ & 1.5776 & 11 & $15.94 \%$ & $92.75 \% * * * * *$ \\
$2.0356-2.9516$ & 2.4936 & 3 & $4.35 \%$ & $97.10 \% *$ \\
$>=2.9516$ & 3.4096 & 2 & $2.90 \%$ & $100.00 \% *$ \\
\hline
\end{tabular}

Let us estimate the matrix of paired correlation coefficients. It is believed that significant correlation coefficients in absolute terms exceeding $0.7-0.8$ indicates multicollinearity.
The results of the evaluation of the correlation matrix between the variables are shown in Table 5. As we see, the correlation coefficients exceed the values of $0.7-0.8$.

Table 5.

Correlation Coefficients, Observations 1 - 69. 5\% Critical Values (Bilateral) $=0.2369$ for $n=69$

\begin{tabular}{llllll}
\hline 1_GHS & 1_GII & 1_RLI & 1_UNT & 1_EPI & \\
\hline 1.0000 & 0.1864 & 0.6428 & 0.0237 & 0.3766 & 1_GHS \\
& 1.0000 & 0.4844 & 0.5087 & 0.4160 & 1_GII \\
& & 1.0000 & 0.2719 & 0.6143 & 1_RLI \\
& & 1.0000 & 0.4777 & 1_UNT \\
& & & 1.0000 & 1_EPI \\
\hline
\end{tabular}

Using data of two indicators (1_PPPI, 1_RLI) for 69 countries with different levels of economic development, it is possible to build a graphical model that shows the relationship between private investment in PPP and the Rule of Law Index (Figure 2). The Rule of Law Index in the presented model received the lowest P-value 0.0009 . 


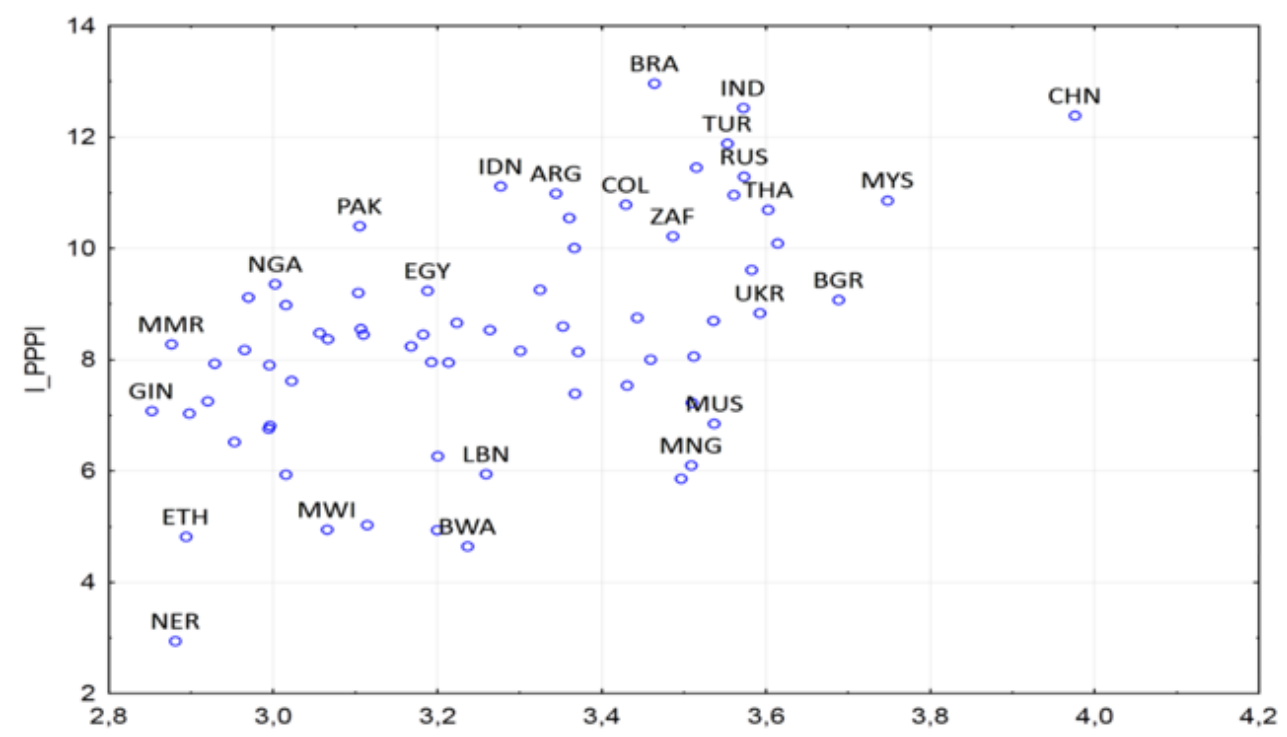

Figure 2. The Relationship between Private Investment in PPPs and the Rule of Law Index

The results obtained in the study require additional explanations regarding their reliability and comparison with similar approaches or studies described in scientific literature.

\section{Discussion}

Analysis of the dependence of the factor that indicates the level of PPP development in the country (the amount of private investment in PPP projects) on the factors that describe social responsibility proves the importance of certain indicators. Regarding the features of the study, it should be noted that the available input data (Global Health Security Index, Environmental Performance Index, Global Innovation Index, Rule of Law Index and Unemployment Rate) were taken for 2019-2020 and do not take into account data for past periods. Given the incomplete set of data by countries for each of the variables, it was not possible to fully consider the countries, so we used data on 69 countries, which are mostly low-level or developing countries. The question arises on the need to expand the data set for most countries in terms of obtaining empirical data, which involves, first of all, calculations for individual countries where the relevant data are not available.

In addition, the considered factors of social responsibility of PPP projects, obtained from research (Chen et al., 2019; Osei-Kyei et al., 2019; Yu et al., 2018) should be expanded in future similar works, which may be an objective for researchers of this issue.

The next limitation is the author's selection of indicators that can describe the social responsibility factors identified in the study (Global Health Security Index, Environmental Performance Index, Global Innovation Index,
Rule of Law Index and Unemployment Rate). It is advisable to use other indicators and expand their range in subsequent studies.

In an increasingly globalized economy, governments continue to transfer public service management to private entities through publicprivate partnerships, thus implementing mechanisms for decentralizing public administration. In the New Public Management paradigm, PPPs are seen as a New Public Management tool used by public sector bodies to activate third parties to implement infrastructure projects, organize and maintain relevant agent networks throughout the project life cycle. Although recent research has examined in detail the main institutional factors contributing to the successful development of PPPs, there have been few attempts to "combine the conceptual foundations of PPP institutional maturity (legitimacy, trust and potential) with the broader theoretical paradigm of the New Public Management" (Joudyian et al., 2021, p. 7).

The PPP agreement requires each stakeholder to take the initiative on certain issues, and therefore PPP management should anticipate that the leading role in the decentralization of management shifts from one party to another depending on changing situations and circumstances. PPP agreements can last for many years, and it is extremely important for partners to trust each other, as this is the basis for their willingness to negotiate at any time during the term of the agreement to help each other. In addition, as PPPs exist in a project management environment, PPP arrangements require each stakeholder to assume certain management 


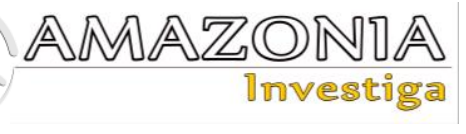

functions within the decentralization of public administration. Therefore, trust will help to smooth the process of shifting leadership from one party to another (Som, Omar, Ismail \& Alias, 2020). Many governments begin to realize their responsibilities and require companies which implement projects that have a huge impact on society to develop strategies and become proactive to ensure sustainability and achieve the Sustainable Development Goals (Aarseth et al., 2017).

The main feature of social responsibility is the company's readiness to implement social aspects in the decision-making process, to be responsible for the consequences of their solutions on society. The important measures in the social sphere are labour protection and safety of their employees, effective employment policy, training, employment of people with disabilities in the labour market, the adoption of the principle of equal opportunities (Mulej, O'Sullivan \& Štrukelj, 2021).

Social responsibility also influences the factors that contribute to the quality of life, combining these ideas with the concept of sustainable development. Sustainable development is an idea whose guiding principles should lead to an improvement in the quality of life. Creating a quality of life involves responsibility for the results of activity, which should serve stakeholders, not just business owners or shareholders (Mulej, O'Sullivan \& Štrukelj, 2021).

Social responsibility integrates social, environmental and ethical human rights, as well as consumer issues into the process (Reshma, 2017). Social responsibility is an important issue of PPPs, as it has become a program of many governments to promote sustainable development that meets the needs of today without compromising the ability of future generations to meet their own needs (Patil \& Laishram, 2016). The concept of social responsibility "has become important in PPP projects because many past projects have not had sufficient social benefits, such as employment opportunities, reliable service delivery, environmental protection, and accessibility" (Osei-Kyei \& Chan, 2016, p. 175).

The category of environment refers to the conservation and management of resources, as well as the promotion of environmental protection at the project site (Bjärstig, 2017). The study by Raza Shah and Yousufi (2021) shows that investment in particular PPP projects

degrades the ecological parameters of the environment. At the same time, there are studies proving the positive impact of PPP on the ecological condition (Pan, Chen, Zhou \& Kong, 2020). Thus, it is still difficult to find unambiguous convincing arguments in the existing scientific literature about the direct relationship between the development of PPP and the ecological condition. This dependence is traced in some projects, while in others we have an adverse data. The results of the study confirm the thesis that there may be no clear link between investment in PPPs and the ecological condition.

The high level of institutional quality reflected in the country's regulatory framework, ensures that PPP projects make optimal use of available resources and work efficiently (Deep, Kim \& Lee, 2019). Transparency increases public confidence in civil servants and improves the overall positive perception of social responsibility arrangements under PPP projects (Osei-Kyei \& Chan 2017). Ensuring transparency and the fight against corruption is crucial to gaining a positive perception of PPPs by the general public (Osei-Kyei, Chan, Javed \& Ameyaw, 2017).

Important success factors for PPPs include regulation, transparency, clear political leadership, the right to vote and accountability, government efficiency, and the fight against governance-related corruption (Pérez-D'Oleo et al., 2015). Countries that have improved the quality of regulation and anti-corruption policies may gradually attract more investment in PPPs. Adequate legal framework reduces management uncertainty for PPPs (Fleta-Asín, Munoz \& Rosell-Martınez, 2020). The study confirmed the highest dependence between investing in PPPs and indicators that describe the rule of law.

Although such studies as Carbonara and Pellegrino (2020) note that PPPs cannot be considered a panacea for innovation, there is growing support for research into the links between the sustainability of innovation in PPPs (Ma et al., 2019). It is necessary to dwell on the result obtained in the study that investment in PPPs has a reverse effect on innovation. This may indicate a shortage of funds, and PPP funding provides only a standard approach to project implementation. The development of innovations requires constant R\&D funding, and in a situation of resource shortage this leads to a choice - by increasing the funding of PPP projects, innovation development will experience a funding gap. Diyamett and Diyamett (2019) present a similar understanding 
of the situation. Roumboutsos and Saussier (2014) showed that investment in innovation is directed at those areas that have a direct impact on the benefit of the private party, mainly by reducing operating costs and maintenance costs. Thus, it is possible to assume that innovation processes are intensified in the case of redistribution of funds by reducing funding of PPP projects.

The Global Health Security Index assesses the security and capabilities of countries in the health sector. There is a positive correlation between data on the level of health care and the development of PPP, which is confirmed by PPP research in the health care system (Joudyian et al., 2021).

The researchers Kruhlov and Tereshchenko (2019) identified positive impact of PPP development on job creation. As a result of the creation of more jobs over long periods of development, unemployment should theoretically decrease. The expected result of the study is that PPP is a catalyst for job creation through active infrastructure projects (Matsolo, 2018), and the results of PPP projects reduce unemployment (Geraghty, 2018), as demonstrated by the results of our study.

As we can see, the processes of decentralization of public administration, implemented in the course of public-private partnership, not only have a positive impact on economic indicators, but also can produce social results using social responsibility approaches. The study identified a relationship between investment in PPP development and social responsibility factors (innovation, environment, health, rule of law and unemployment reduction), which were characterized by the following indicators: The Global Health Security Index, the Environmental Performance Index, the Global Innovation Index, the Rule of Law Index and the Unemployment Rate. But this approach requires further elaboration of the results of the study of social responsibility under public-private partnership.

\section{Conclusions}

Thus, when implementing PPP projects, the state mainly tries to solve the economic issues, namely: attract the necessary resources, create modern infrastructure, implement sustainable development goals. The public-private partnership relies on the approach that involves reducing public impact, changing the emphasis of public administration by decentralizing powers between the parties to economic and legal relations. Most research on public-private partnerships looks at the private sector as partners in the supply of services and participants in infrastructure construction.

This approach limits the opportunities for the private sector in public administration. The transfer by the state to private partners of rights (property, resources, finances) and powers (profit, risks) should additionally take into account models that expand the functions of the state - administration, control, regulation.

The study proves the need to consider indicators of social responsibility in the course of publicprivate partnership. It was identified that important factors of social responsibility are innovation, environmental protection, health, accountability and legality, and unemployment reduction. Econometric analysis of the factors used as indicators of social responsibility showed some dependencies: a significant correlation between the development of PPP and the rule of law, as well as the inverse correlation between private investment in PPP and innovation. The results of the analysis prove the relevant effects of PPP activities, but the features of such effects may be related to lack of funds, reduction of operating costs, the specifics of infrastructure projects, and other factors. In the future, the state policy of PPP development as a mechanism of decentralization of power in the governance system should focus on further deepening the opportunities for social responsibility, which play an important role in achieving the Sustainable Development Goals, improving quality of life and solving many socially important issues.

\section{Bibliographic references}

Aarseth, W., Ahola, T., Aaltonen, K., Økland, A., $\&$ Andersen, B. (2017). Project sustainability strategies: A systematic literature review. International Journal of Project Management, 35(6), 1071-1083. https://doi.org/10.1016/j.ijproman.2016.11.0 06

Bjärstig, T. (2017). Does collaboration lead to sustainability? A study of public-private partnerships in the Swedish mountains. Sustainability (Switzerland), 9(10), 1685. https://doi.org/10.3390/su9101685

Carbonara, N., \& Pellegrino, R. (2020). The role of public private partnerships in fostering innovation. Construction Management and Economics, 38(2), 140-156. https://doi.org/10.1080/01446193.2019.1610 184 


\section{AMAZONDA}

Casady, C. B., Eriksson, K., Levitt, R. E. \& Scott, W. R. (2019). (Re)defining publicprivate partnerships (PPPs) in the new public governance (NPG) paradigm: an institutional maturity perspective. Public Management Review, 22(2), 161-183. https://doi.org/10.1080/14719037.2019.1577 909

Chen, C., Yu, Y., Osei-Kyei, R., Chan, A. P. C., $\& \mathrm{Xu}$, J. (2019). Developing a project sustainability index for sustainable development in transnational public-private partnership projects. Sustainable Development, 27(6), 1034-1048. https://doi.org/10.1002/sd.1954

Deep, A., Kim, J. \& Lee, M. (Eds.). (2019). Realizing the potential of public-private partnerships to advance Asia's infrastructure development. Manila, Philippines: Asian Development Bank.

Diyamett, B., \& Diyamett, L. D. (2019). The role of public-private partnerships in innovation for development: Lessons from Africa. New Dehil, India: Observer Research Foundation.

Dutta, S., Lanvin, B., \& Wunsch-Vincent. S. (Eds.). (2020). The global innovation index 2020: who will finance innovation? 13th edition. Ithaca: Cornell INSEAD WIPO.

Economist Intelligence Unit. (2020). Global health security index 2019 Retrieved from https://www.ghsindex.org/

Fleta-Asín, J., Munoz, F. \& Rosell-Martınez, J. (2020). Public-private partnerships: determinants of the type of governance structure. Public Management Review, 22(10), 1489-1514. https://doi.org/10.1080/14719037.2019.1637 014

Geraghty, B. M. (2018). Public private partnerships for economic development: impacts on shrinking cities (Master's Thesis). Binghamton University, Binghamton, NY. proquest.com/openview/8235da93a4037ab8 a7c01617c47800da/1?pq-

origsite $=$ gscholar $\& \mathrm{cbl}=18750$

Hinson, R. E., Avomyo, F., Kuada, J., \& Asante, F. A. (2017). Corporate social responsibility and international business: Examining the nexus and gaps from a developing economy perspective. International Journal of Corporate Social Responsibility, 2(5), 1-14.

Joudyian, N., Doshmangir, L., Mahdavi, M., Tabrizi, J. S., \& Gordeev, V. S. (2021). Public-private partnerships in primary health care: a scoping review. BMC Health Services Research, 21(1), 1-18. https://doi.org/10.1186/s12913-020-05979-9
Kruhlov, V. V., \& Tereshchenko, D. A. (2019). Public-private partnership as tool for developing regional labor potential. Science Innovations, 15(6), 5-13. https://doi.org/10.15407/scine15.06.005

Ma, L., Li, J., Jin, R., Ke, Y. \& Yuan, J. (2019). A holistic review of public-private partnership literature published between 2008 and 2018. Advances in Civil Engineering, S2019, Art. 7094653. https://doi.org/10.1155/2019/7094653

Malik, S., \& Kaur, S. (2020). Multi-dimensional public-private partnership readiness index: a sub-national analysis of India. Transforming Government: People, Process and Policy (Ahead of Print). https://doi.org/10.1108/TG06-2020-0107

Matsolo, N. (2018). Are public private partnerships catalysing economic growth in sub-Saharan Africa? (Master's thesis). University of Cape Town, Cape Town, South Africa.

Mota, J.A., \& Moreira, A.C. (2015). The importance of non-financial determinants on public- private partnerships in Europe. International Journal of Project Management, 33(7), 1563-1575.

Mulej, M., O’Sullivan, G., \& Štrukelj, T. (Eds.). (2021). Social responsibility and corporate governance. Volume 2: Policy and practice. Palgrave studies in governance, leadership and responsibility. Cham, Switzerland: Palgrave Macmillan.

Osei-Kyei, R., \& Chan, A. P. C. (2016). Developing transport infrastructure in SubSaharan Africa through public-private partnerships: Policy practice and implications. Transport Reviews, 36(2), 170186.

https://doi.org/10.1080/01441647.2015.1077 288

Osei-Kyei, R., \& Chan, A. P. C. (2017). Implementation constraints in public-private partnership: Empirical comparison between developing and developed economies/countries. Journal of Facilities Management, 15(1), 90-106. https://doi.org/10.1108/JFM-07-2016-0032

Osei-Kyei, R., Chan, A.P., Javed, A. A., \& Ameyaw, E. E. (2017). Critical success criteria for public-private partnership projects: International experts' opinion. International Journal of Strategic Property Management, 21(1), 87-100. https://doi.org/10.3846/1648715X.2016.124 6388

Osei-Kyei, R., Chan, A. P., Yu, Y., Chen, C., Ke, Y., \& Tijani, B. (2019). Social responsibility initiatives for public-private 
partnership projects: A comparative study between China and Ghana. Sustainability, 11(5), 1338. https://doi.org/10.3390/su11051338

Pan, D., Chen, H., Zhou, G., \& Kong, F. (2020). Determinants of public-private partnership adoption in solid waste management in rural China. International Journal of Environmental Research and Public Health, 17(15), 5350. https://doi.org/10.3390/ijerph17155350

Patil, N. A., \& Laishram, B. (2016). Publicprivate partnerships from sustainability perspective - a critical analysis of the Indian case. International Journal of Construction Management, 16(2), 161-174. https://doi.org/10.1080/15623599.2016.1146 113

Patil, N. A., Tharun, D., \& Laishram, B. (2016). Infrastructure development through PPPS in India: Criteria for sustainability assessment. Journal of Environmental Planning and Management, 59(4), 708-729. https://doi.org/10.1080/09640568.2015.1038 337

Pérez-D’Oleo, J., Castro, C., Herraiz, I., \& Carpintero, S. (2015). The influence of the institutional environment on public-private partnership transport projects. WIT Transactions on The Built Environment, 146, 399-410.

Popa, R. A. (2015). The corporate social responsibility practices in the context of sustainable development: The case of Romania. Procedia Economics and Finance, 23, 1279-1285.

Raza, S. A., Shah, S. H., \& Yousufi, S. Q. (2021). The impact of public-private partnerships Investment in Energy on carbon emissions: evidence from nonparametric causality-inquantiles. Environmental Science and Pollution Research, 28, 23182-23192. https://doi.org/10.1007/s11356-020-12306-6

Reshma, P. A (2017). Theoretical glimpse on corporate social responsibility. International Journal of Economics, Commerce and Management, 4, 44-48.

Rocca, M. E. (2017). The rising advantage of public-private partnerships. McKinsey \& Company. Retrieved from https://www.mckinsey.com/industries/privat e-equity-and-principal-investors/our- insights/the-rising-advantage-of-publicprivate-partnerships

Roumboutsos, A., \& Saussier, S. (2014). Publicprivate partnerships and investments in innovation: the influence of the contractual arrangement. Construction Management and Economics, 32(4), 349-361. https://doi.org/10.1080/01446193.2014.8958 49

Sheppard, G., \& Beck, M. (2016). The evolution of publice-private partnership in Ireland: A sustainable pathway? International Review of Administrative Sciences, 84(3), 579-595. https://doi.org/10.1177/0020852316641494

Som, R. M., Omar, Z., Ismail, I. A., \& Alias, S. N. (2020). Understanding leadership roles and competencies for public-private partnership. Journal of Asia Business Studies, 14(4), 541-560. https://doi.org/10.1108/JABS-01-2019-0027

Wendling, Z. A., Emerson, J. W., de Sherbinin, A., Esty, D. C. et al. (2020). 2020 environmental performance index. New Haven, CT: Yale Center for Environmental Law \& Policy. Retrieved from https://epi.yale.edu/

World Bank. (2019). Country-level PPP profiles and links to key data and resources. Retrieved from https://pppknowledgelab.org/countries

World Bank. (2020). Unemployment, total (\% of total labor force) (modeled ILO estimate) Retrieved from https://data.worldbank.org/indicator/SL.UE M.TOTL.ZS

World Justice Project. (2020). Rule of law index 2020 [Online]. Available: Retrieved from https://worldjusticeproject.org/sites/default/f iles/documents/WJP-ROLI-2020Online_0.pdf

Yu, Y., Osei-Kyei, R., Chan, A. P. C., Chen, C., \& Martek, I. (2018). Review of social responsibility factors for sustainable development in public-private partnerships. Sustainable development, 26(6), 515-524. https://doi.org/10.1002/sd.1737

Yurdakul, H., Kamaşak, R., \& Öztürk, T. Y. (2021). Macroeconomic drivers of Public Private Partnership (PPP) projects in low income and developing countries: A panel data analysis. Borsa Istanbul Review (Ahead of print). https://doi.org/10.1016/j.bir.2021.01.002 